\title{
First Survey on the Edible Non-Wood Forest Products Sold in Uíge Province, Northern Angola
}

\author{
M. Mawunu, P. Macuntima, T. Lautenschläger, L. Masidivinga, N. Luyindula, \\ K.N. Ngbolua and L. Lukoki
}

\begin{abstract}
This study aimed to inventory, identify, characterize and valorize the various edible non wood forest products (NWFPs) sold in Uíge Province. Data for this study were collected between October 2016 and February 2020. A total of 156 edible NWFPs sellers were individually interviewed using semi-structured questionnaire at the 30 sales sites. $93.5 \%$ of edible NWFP sellers were female and $6.5 \%$ male. The main edible NWFPs sold in Uíge Province are animal products with 47 species, of which $48.9 \%$ are Mammals, $21.3 \%$ Insects, 12.8\% Actinopterygii, 6.4\% Birds, 8.5\% Reptiles, and $2.1 \%$ Sarcopterygii. Plants represent $38.5 \%$ ( 35 species) of the edible NWFPs sold in the study area, of which $78.8 \%$ are Dicotyledones, 21.2\% Monocotyledones, 2.9\% Gnetophytes and $2.9 \%$ Pteridophytes. Besides, Mushrooms account for barely $9.9 \%$ of the edible NWFPs sold in this region. On the other hand, edible NWFPs are sold on formal and informal markets, in the bus parking lots, taxi runk, roadsides, restaurants and at the seller' homes. For the sale of edible forest products, the vendors use non-standardized measuring units. The income generated by the sale of NWFPs is used to solve socio-economic problems in the household, including the purchase of basic necessities, health care, clothing, cosmetics, school materials, well-being, etc.
\end{abstract}

Index Terms - Uíge Province, Angola, Surveys, Edible nonwood forest products, Systematic identification, Market information.

\section{INTRODUCTION}

Non-wood forest products (NWFPs) are defined as biological materials other than round wood or timber that may originate from natural ecosystems, natural forest plantations or agroforestry systems used in households, marketed or having socio-cultural or spiritual significance [1]. According to Food and Agriculture Organization of the United Nations (FAO), "FAO [2], NWFPs are non-wood biological goods derived from forests, other wooded land or trees outside forests. NWFPs can be harvested from the wild or produced and harvested from forest plantations, agroforestry schemes or trees outside forests". Also, according to FAO [1], NWFPs are all biological materials

Published on December 7, 2020.

M. Mawunu, Kimpa Vita University, Uíge, Angola.

(e-mail: m.mawunu2000@gmail.com)

P. Makuntima, Kimpa Vita University, Uíge, Angola.

L. Masidivinga, Kimpa Vita University, Uíge, Angola.

T. Lautenschläger, Technische Universität, Dresden, Germany.

N. Luyindula, University of Kinshasa, Kinshasa, Democratic Republic of Congo.

K. N. Ngbolua, University of Kinshasa, Kinshasa, Democratic Republic of Congo and University of Gbado-Lite, Gbado-Lite, Democratic Republic of Congo.

L. Lukoki, University of Kinshasa, Kinshasa, Democratic Republic of Congo. other than wood that are extracted from the forest for human use; NWFPs include all tangible, natural, artisanal or processed products derived from forests or other lands with similar uses, other than wood. They also include foods, medicines, oils, resins, gums, tannins, bamboo, firewood, charcoal, and game sold and consumed locally, nationally, or internationally.

In this study, NWFPs are classified into three categories: plants and plant products; animals and animal products [3]. The last category consists of mushrooms [4].

In the most tropical countries, particularly in sub-Saharan Africa, NWFPs play an important role in daily life by ensuring the well-being of local communities. Not only used for local consumption, but NWFPs also function as commodities that can be traded on local, regional, national, and international markets. The sale of NWFPs is a response to daily needs, demand for employment, a source of income [1], [5] and economic diversification.

According to Grieg-Gran et al. [6], African economies are often anchored in abundant natural resources from the myriad ecosystems that span the continent. Forests are an integral part of Africa's economic fabric, providing for subsistence needs for food, energy and medicinal plants and providing key regulating and supporting ecosystem services of local, national and global importance.

Numerous studies in different parts of the African continent e.g. [7]-[11] have shown the importance of NWFPs, both commercial and non-commercial, as well as a source of livelihoods, wild foods, animal fodder and wood fuels for African people. On the other hand, FAO estimates [12] show the commercial importance of NWFPs, with an estimated value of gross production in Africa in 2011 placed at US\$ 5.3 billion, which represents 0.3 per cent of the region's GDP. As for Ndoye et al, [13], NWFP markets are also important at the regional and international levels, as they provide income to stockholders directly involved in a development project. Moreover, the importance of NWFPs is well established, as their development can generate added value for local populations [14]. On the other hand, NWFPs are emerging on the world scene as a tool for establishing sustainable forest communities. They represent jobs for various sectors of society and increase the benefits from forests, involving local expertise and culture [15].

Indeed, for centuries NWFPs have played an important role of food and trade in Africa [16]. More than half of the African population depends on natural forest resources [17]. The consumption and sale of NWFPs such as edible and medicinal plants and game are likely to contribute to the food and nutritional security of population [2], [9]. According to Brian et al. [18], NWFPs can provide sources 
of income and opportunities for poverty reduction in both rural and urban areas. Furthermore, according to Tinde van Andel [19], the most forest products never reach the market, only a small percentage is sold in local and regional markets, which is an important source of financial income. Similarly, Noubissie et al. [20] show that trade in NWFPs generates employment opportunities, substantial income and supports the livelihoods of communities living around the forest. Currently, approximately $75 \%$ of the world's poor depend on NWFPs for their livelihoods, while $80 \%$ of forest populations in developing countries use NWFPs daily. Moreover, according to Chidebere-Mark et al. [21], NWFPs are capable of providing food, health care and income to sustain livelihoods.

Despite numerous studies conducted worldwide on the commerce of edible NWFPs e.g. [1], [16], [2] data on Angola and particularly Uíge Province are still fragmentary [7]-[9] [22]-[25].

Besides, many edible NWFPs are sold daily on rural and urban markets in Uíge Province, so it would be appropriate to carry out a study on these forest products in order to know them better and add value to them.

To our knowledge, no scientific work has been carried out in this part of Angola that has dealt simultaneously with the inventory, characterization, and valorization of edible NWFPs (plants, animals and mushrooms) sold in the province of Uíge.

The present work focuses on three different types of edible forest products marketed in Uíge Province, namely: animals, plants, and wild mushrooms.

The objectives of this study are as follows: (1) To make an inventory of the three types of edible forest products sold in Uíge Province; (2) To identify and characterize them taxonomically; (3) To know the socio-economic profile of edible forest products sellers; and finally; (4) To know the marketing sites and methods of customer loyalty, sales methods, savings and income allocation. Despite the socioeconomic importance of NWFPs, there is little information in the literature on edible forest products sold in Angola, particularly in Uíge Province. This work contributes to the existing data in Angola's NWFPs. The data from this study will be used for sustainable management and the development of market organization strategies for edible forest products to ensure the well-being of local communities in Angola. Also, the study will provide information to students, researchers, international organizations, policy makers and the general public.

\section{MATERIALS AND METHODS}

\section{A. Description of the study area and selection of respondents}

The Uíge Province, located in the north of Angola, covers an area of $58,698 \mathrm{~km} 2$ and has a population of more than 1.4 million [26]. Uíge has a tropical savannah climate with a dry season (Sivu or Mbangala in the Kikongo language) [8] from May to September and annual rainfall of 900 to 1500 $\mathrm{mm}$; the average annual temperature of the capital of Uíge is $23{ }^{\circ} \mathrm{C}$ [27], [28]. The province of Uíge enjoys excellent edaphoclimatic conditions (extensive arable land and regular rainfall) and also has a dense hydrographic network that waters the region (7). The economy of Uíge province is mainly based on subsistence agriculture, livestock, hunting, small trade [9], [29] and traditional fishing.

Data for this study were collected between October 2016 and February 2020. The choice of the study area was made after a pre-survey that confirmed the existence of edible NWFPs for sale in the markets of the province of Uíge. Field visits were carried out in 15 of the 16 municipalities of the province (Fig. 1). Respondents were selected based on their availability and socio-economic activity, sale of edible NWFPs. The method adopted for data collection was the ethnobiological and socio-economic survey applied by Monizi et al. [7], [8]. It first consists of drafting a questionnaire that allows for a better understanding of the different types and uses of edible NWFPs sold in the Study Area. Also, data collection was carried out through direct field observation and individual interviews with sellers of edible NWFPs.
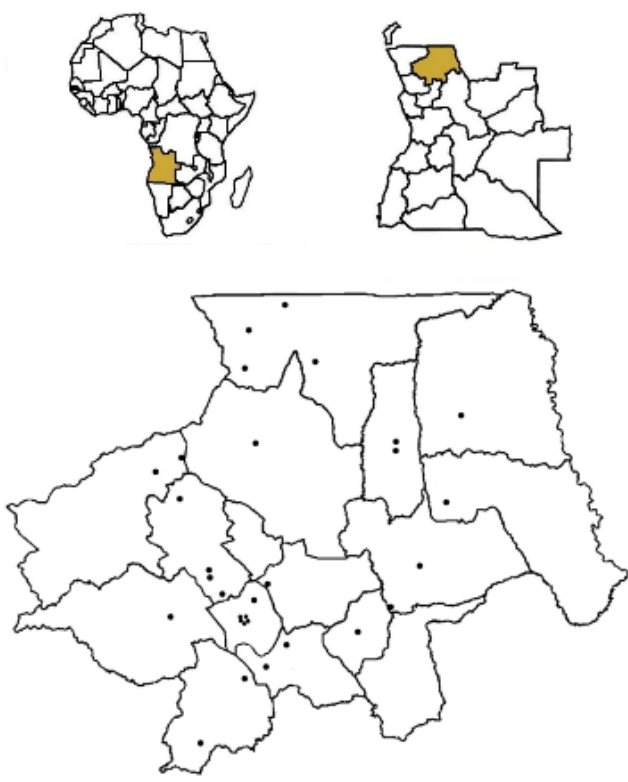

Fig. 1. Location of the study area and edible NWFP sales sites in Uíge Province, Republic of Angola.

\section{B. Biological Material}

The biological material to be studied consists of edible animals, plants and mushrooms. For taxonomic identification, several books and works have been used: Monizi et al. [7], Lautenschläger et al. [25], [30]-[34].

\section{Questionnaire}

The survey questionnaire was divided into three sections: (1) Vendor's data (age, gender, education, marital status and main source of income); (2) Biological material (scientific and vernacular name(s), the origin of NWFPs, conservation status, uses of plant organs); (3) Market information (sales, pricing and customer loyalty patterns, sales locations, sales methods and units of measurement, savings and income allocation). In addition, the study was based on targeted sampling. Eligibility criteria were the sale of edible NWFPs and the availability of respondents in anthropological surveys. The semi-structured questionnaire was submitted 
orally to the various informants.

\section{Ethnobiological and Socio-economic Surveys}

Biological information on the species of plants, animals and fungi listed in this study was obtained from the edible NWFP vendors interviewed in the province of Uíge. The purpose of this study is to learn about the different types of edible NWFPs sold in this province, as well as their methods and locations of sale, among others. A total of 156 informants were involved in this study, including 149 women and 7 men. The individual anthropological interviews were conducted in Kikongo or Portuguese, depending on the language spoken by the respondent.

\section{E. Statistical Analyses}

The ethnobiological and socio-economic data from this study were analyzed using Statistical Package for Social Sciences (SPSS, Inc., Chicago, USA) version 25.0.

\section{RESULTS AND DISCUSSION}

\section{A. Socio-economic Profile of NWFP Sellers}

A total of 156 vendors from 30 edible NWFP marketing sites were interviewed in Uíge Province. Of all the edible NWFP vendors surveyed, women are in the majority $(93.5$ $\%$ ) than men who represent only $6.5 \%$ of the vendors. The results of this study attest to previous studies that the sale of edible NWFPs is a women's domain. Besides, Monizi et al. [7] who worked in the same region and showed that, the sale of edible NWFPs is mostly (92\%) practiced by women. Similarly, Monizi et al. [8] report that $83 \%$ of the Raphia wine sellers in this part of Angola are women. According to FAO [1], in Southern Africa, women are particularly involved in the collection and sale of NWFPs. Also, these observations are similar to those reported by FAO [2] that the commercial NWFP sector in Central Africa is more than $80 \%$ dominated by women.

The results of this study also show that the average age of edible NWFP sellers in the study area is 35 years. Referring to this average age, it shows that the profession of edible NWFP sales in this region is exercised by young people who will ensure its continuity for a long time. These results are close to those of Monizi et al. [7], [8] who found in their work an average age of 36 and 38 years, respectively among sellers of Raphia wine and Dracaena Cameroonian leaves in the same region. The study also revealed that the average number of people per household of forest product vendors is 5.8 people. This result is higher than the general national average of 4.6 persons per household obtained in the general population and housing Angola's 2014 census conducted [26].

In addition, the results on anthropological parameters from this study show that, trade is the main $(55.3 \%)$ source of income and employment for edible NWFP sellers in the Study Area. Besides, agriculture and other activities (sale of labour force, public service, etc.) account for $30.6 \%$ and $14.1 \%$ respectively. Regarding civil status, married people predominate with $58.4 \%$ of the people surveyed. People living in separation or divorce represent, $25.5 \%$. On the other hand, the single $(8.7 \%)$ and widows $(7.4 \%)$ are in the minority among the vendors of forest food products in Uíge.
Also, literate people predominate (92.4 \%) among vendors of NWFPs for food use than those who have never been to school $(7.6 \%)$. These results are similar to those of Monizi et al. [8] who showed that $95 \%$ of the stockholders in the wine value chain of Raphia in Uíge province are literate. In the same vein, Monizi et al. [7], also showed that edible NWFPs with Dracaena Cameroonian leaves attract both educated and never attended school with $75.7 \%$ and $24.3 \%$ respectively.

Finally, the results of this study show that sellers of edible NWFPs in Uíge Province have an average of 5 years' experience in their business. Trade in edible NWFPs seems to be relatively beneficial, as $63.7 \%$ of the sellers have more than 5 years of experience in the sale of these products. On the other hand, those with less than five years of experience represent $36.3 \%$.

\section{B. Biological Characterization of Edible NWFPs}

Three types of edible NWFPs (animals, plants and mushrooms) available for sale in Uíge Province were identified in this study. The biological diversity of these NWFPs is documented in Tables 1 to 3.

\section{NWFPs of plant origin}

\subsection{Systematic description}

A total of 35 species of plant NWFPs were identified from edible NWFP vendors in the Study Area, divided into 29 genera and 23 botanical families (Table 1). Analysis of the numerical importance of the families in the floristic list (Table 1) shows that the botanical families best represented in number of species are:

Apocynaceae (4 species), Fabaceae and Zingiberaceae with 3 species. On the other hand, the families Annonaceae, Arecaceae, Asteraceae, Burseraceae, Euphorbiaceae, and Loganiaceae each have two species. The least represented families are those of Anisophylleaceae, Asparagaceae, Bombaceae, Celastraceae, Cucurbitaceae, Dennstaedtiaceae, Gnetaceae, Malvaceae, Moraceae, Myrtaceae, Piperaceae and Verbenaceae each with only one species. In addition, Angiosperms constitute $94.3 \%$ of the food plant NWFPs sold in the province of Uíge with a predominance of Broadleaf $(74.3 \%)$ and $20.0 \%$ of Monocotyledons. Finally, Gymnosperms (Gnetum africanum) and Polypodiopsida (Pteridium aquilinum) only have one species each, representing $5.7 \%$ of all edible plant NWFPs identified in this study.

\subsection{Used edible parts of plants}

The results of this study on edible parts of plants used (Table 1) reveal that fruits and fruit pulps are the majority of plant parts $(44.2 \%)$ sold in the province of Uíge as NWFPs for food use. Also, leaves and seeds occupy $20.9 \%$ and 14.0 $\%$ respectively. Finally, the other edible organs of the plants are shoots and stems $(7.0 \%)$, saplings $(4.7 \%)$, bark $(4.7 \%)$, roots $(2.3 \%)$ and inflorescences $(2.3 \%)$. In addition, Mawunu et al., [9] recorded 7 edible parts sold in the municipality of Ambuila (Uíge Province), of which $25 \%$ of the leaves, $25 \%$ of the beans and $50 \%$ of the fruits and seeds, respectively.

\subsection{Uses of edible plant organs}

Examination of the results of this study on the food use of plant organs (Table 1) shows that fruits and fruit juices are the most widely used (38.5\%). In addition, the other food 
uses identified are leafy vegetables (20.5\%), spices (17.9 $\%)$, tea $(10.3 \%)$, palm oil and wines of Elaeis guineensis and Raphia spp (7.7\%) and nibble/amuse-geuele (5.1\%). On the other hand, Mawunu et al. [9], identified 6 uses of the edible parts of plants sold in the municipality of Ambuila (Uíge Province), beverages (33.3\%), vegetables $(16.7 \%)$, snacks $(16.7 \%)$, teas $(16.7 \%)$ and spices $(16.7$ $\%)$.

\section{Animal NWFPs}

\subsection{Systematic description}

The results of the inventory in Table 2 show that 47 species of wild animals sold in the province of Uíge belong to 30 zoological families. The zoological families of Bovidae, Saturiniidae, Muridae and Viverridae are the most represented with 5, 4, 3 and 3 species respectively. And the rest of the families have only one or two species. These are Varanidae, Testudinidae, Termitidae, Apidae, Cercopithecidae, Channidae, Cichlidae, Clariidae, Curculionidae, Cyprinidae, Gryllinidae, Hystricidae, Leporidae, Manidae, Muridae, Nesomyidae, Noctuidae, Numidididae, Passeridae, Phasianidae, Protopteridae, Pteropodidae, Pythonidae, Sciuridae, Termitidae and Testudinidae. Mammals occupy $48.9 \%$ (23 species) of the NWFPs of animal origin sold in the province of Uíge. Furthermore, in this class of mammals, rodents dominate with 10 species, followed by Artiodactyls (6 species), Carnivores (4 species), Pholidotes (1 species), Chiroptera (1 species), and Primates (1 species). In addition, Insects occupy $21.3 \%$ (10 species) of the edible NWFPs sold in the study area, including 6 species of Lepidoptera, 1 species of Blattodea, 1 species of Coleoptera, 1 species of Hymenoptera, and 1 species of Orthoptera. Finally, the other inventoried classes of animals are Actinopterygii (12.8\%, 6 species), Birds with (6.4\%, 3 species), Reptiles (8.5\%, 4 species), and Sarcopterygii (2.1\%, 1 species).

\section{Mycological NWFPs}

\subsection{Systematic description}

The results of this study (Table 3) show that the 9 species of wild edible fungi recorded in the province of Uíge all belong to the class Agaricomycetes and are distributed in 4 different mycological families. The family Lyophyllaceae is the best represented with 5 species (Termitomyces microcarpus, Termitomyces titanicus, Termitomyces aurantiacus, Termitomyces mammiformis, Amanita loosii). In addition, the family Auriculariaceae occupies the second position with 2 species (Auricularia spec., Auricularia cornea). In addition, the rest of the families each have one species, the Cantharellaceae (Cantharellus sp.) and the Russulaceae (Lactarius edulis).

\section{Market-related Information}

A total of 91 edible NWFPs were inventoried at markets and restaurants in the Study Area. 95.6\% (84 species) of the NWFPs marketed in the province of Uíge are local products. In addition, the other (2) edible NWFPs sold in this province come from exclusively abroad, the Democratic Republic of Congo (DRC). These are Nzombo (Protopterus dolloi) and Mungusu (Parachanna obscura)). Furthermore, most of Nsafu (Dracryodes edulis) and Nkuati (Cirina forda) sold to Uíge and Luanda (capital of Angola) comes from RDC. These four forest food products are part of the cross-border trade between Angola (Uíge province) and DRC (Kongo Central province).

\section{Units of Measurement and Methods of Sale of Edible NWFPs}

The results of this study revealed that there are no standardized units of measurement used in the marketing of edible NWFPs in Uíge Province. As a result, the local population uses an improvised variety of local units or measuring instruments (Tables 1,2 and 3) used for the sale of forest products. These instruments are adapted according to the nature or physical state (liquid or solid) of the edible NWFPs on sale in the study area. For example, stems (Crassocephalum montuosum, C. rubens, Lippia multiflora) (Fig. 2a), leaves (Gnetum africanum) (Fig. 2b), Dracaena camerooniana, Mondia whitei, Salacia pynaertii, shoots (Pteridium aquilinum) (Fig. 2c), inflorescences (Cymbopogon densiflorus) (Fig. 2d) and roots (Mondia whitei) are sold in bunches. Fruit pulp (Adansonia digitata) is sold in heaps, buckets (Fig. 2e) or plastic basins, or even in $50 \mathrm{~kg}$ bags. Also, fruits (Afromomum albo-violaceum, A. angustifolium) (Fig.2f), Anisophyllea quangensis, Canarium schweinffurtii, Dacryodes edilus, Landolphia lanceolata, Strychnos cocculoides), seeds (Cola acuminata, Monodora angolensis, Piper guineense, etc. (Fig. 2g), Treculia africana) and bark (Ochna afzelii subsp. mechowiana, Scorodophoeus zenkeri) are sold in heaps or small plastic basins or even in metal cans, commonly called kilos (Canarium schweinffurtii, Fig. 2h). In addition, liquid edible NWFPs such as honey, forest wines (wine from Elaeis guineensis and Raphia spp.) and red palm oil (Elaeis guinensis, Fig. 2i) are sold in transparent bottles of 0.5 or 1 liter or in plastic cans of 5 or 20 liters. Also, edible NWFPs of animal origin, such as Seke (Passer spp.), Cricket (Brachytrupes membraceus) (Fig. 2j), Catfish (Clarias angolensis) (Fig. 2k), Nkusu (Lemniscomys Griselda) and Mbende (L. striatus) (Fig. 21), Sheatfish (Chanallabes apus), etc. are sold in skewers. Python (Python sebae) and outhers game, Cane-rat (Trhyonomys swinderianus (Fig. 2m), Antelope (Tragelaphus spekii) (Fig. 2n)) including some large fish such as Mungusu (Parachanna obscura) (Fig. 2o) and Nzombo (Protopterus dolloi) (Fig. 2p) are also sold in heaps of small pieces; in large pieces or whole. Finally, mushrooms are sold in heaps (Auricularia cornea) (Fig. 2q), buckets or small basins (Termitomyces aurantiacus) (Fig. 2r) or even as a rosary, as in the case of Mvumbu (Lactarius edulis).

\section{E. Price Determination Methods}

Selling prices are generally set according to market habits. Prices are determined according to seasonality, the law of supply and demand, the appearance of the buyer (belonging to a given social class), the quality of the product (state of perishability), the size or thickness of the product, and also other factors such as the cost of production. Besides, it was noted that there is almost no labelling or price display $(99.3 \%)$ on food NWFPs on sale in Uíge Province. This is a deliberate practice that protects the seller from competition and guarantees the seller a good margin of manoeuvre when it comes to determining the price according to the appearance of the customer. 
TABLE 1: LIST OF EDIBLE VEGETAL NWPF SOLD IN UÍGE PROVINCE, ANGOLA

\begin{tabular}{|c|c|c|c|c|c|c|}
\hline Local Names & Scientific name & Family & Edible parts & Uses & $\begin{array}{c}\text { Units and } \\
\text { Modes of sale }\end{array}$ & $\begin{array}{c}\text { Conservation } \\
\text { status }\end{array}$ \\
\hline Bulukutu & Lippia multiflora Moldenke & Verbenaceae & Leaf, stem & Tea & 1 & N. R \\
\hline Bungudi, Bungudia & $\begin{array}{l}\text { Crassocephalum montuosum (S. Moore) } \\
\text { Milne-Redh. }\end{array}$ & Asteraceae & Leaf & Vegetable & 1 & N. R \\
\hline Bungudi, Bungudia & $\begin{array}{l}\text { Crassocephalum rubens (Juss. Ex Jacq.) S. } \\
\text { Moore }\end{array}$ & Asteraceae & Leaf & Vegetable & 1 & N. R \\
\hline Kikaya & Non ident. & Non ident. & Leaf & Tea & 1 & N. R \\
\hline Kumpidi/kampidi & Piper guineense Schumach. \& Thonn. & Piperaceae & Seeds & Spice & 2 & N. R \\
\hline Mabumi, Kalankonki & Strychnos cocculoides $\mathrm{L}$. & Loganiaceae & Fruit & Fruit & $2 ; 3$ & N. R \\
\hline Mahata/Maata & Landolphia lanceolata (K. Schum.) Pichon & Apocynaceae & Fruit & Fruit & $2 ; 3$ & N. R \\
\hline Makanzu & Cola acuminata (Beauv.) Schtt \& Endl. & Sterculiaceae & Nuts & Snacks & 2 & N. R \\
\hline Malombwa & Landolphia owariensis P. Beauv. & Apocynaceae & Fruit & Fruit & $2 ; 3$ & N.R \\
\hline Mampodia & Aframomum stanfieldii Hepper & Zingiberaceae & Fruit & Fruit & $2 ; 3$ & N.R \\
\hline Mansansa ma mfinda & $\begin{array}{l}\text { Aframomum angustifolium (Oliv. \& D. } \\
\text { Hanb.) K. Shum. }\end{array}$ & Zingiberaceae & Fruit & Fruit & $2 ; 3$ & N. R \\
\hline $\begin{array}{c}\text { Mansunja/ } \\
\text { mansansa ma londe }\end{array}$ & $\begin{array}{l}\text { Aframomum albo-violaceum (Ridl.) } \\
\text { K. Schum }\end{array}$ & Zingiberaceae & Fruit & Fruit & $2 ; 3$ & N. R \\
\hline Matombe/mavusu & Raphia spp & Arecaceae & Fruit, Seve & Fruit, wine & $4 ; 5 ; 6$ & N. R \\
\hline Mbidi & Canarium schweinffurtii Engl. & Burseraceae & Fruit & Fruit & $2 ; 7$ & N. R \\
\hline Mbonde/mbondi & Salacia pynaertii De Wild. & Celastraceae & Leaf & Vegetable & 1 & N. R \\
\hline Mfumbwa & Gnetum africanum Welw. & Gnetaceae & Leaf & Vegetable & 1 & Vul. \\
\hline Mfungu/loengo & Anisophyllea quangensis Engl.Henriq. & Anisophylleaceae & Fruit & Fruit & 2 & N. R \\
\hline Mitekua tekua & $\begin{array}{l}\text { Pteridium aquilinum subsp. Africanum (L.) } \\
\text { Kuhn }\end{array}$ & Dennstaedtiaceae & Shoot & Vegetable & 1 & N. R \\
\hline Mpeve & Monodora angolensis Welw. & Annonaceae & Seeds & Spice & $2 ; 7$ & N. R \\
\hline Mungoma ngoma & Erythrina abyssinica DC. & Fabaceae & Bark & Tea & 1 & N. R \\
\hline Munkula & Pterocarpus angolensis DC. & Leguminosae & Leaf & Vegetable & $2 ; 3$ & Vul. \\
\hline Ngo nti, Nkosi nti & $\begin{array}{l}\text { Ochna afzelii subsp. mechowiana (O. } \\
\text { Hoffm.) N. Robson }\end{array}$ & Ochnaceae & Bark & Tea & 1 & N. R \\
\hline Ba dia Ngazi & Elaeis guineensis Jacq. & Arecaceae & Fruit, Seve & $\begin{array}{l}\text { Oil and } \\
\text { palm wine }\end{array}$ & $2 ; 4 ; 6$ & N. R \\
\hline Nkasu & Plukenetia conophora Müll.Arg. & Euphorbiaceae & Fruit & Spice & 2 & N. R \\
\hline N'kizu & $\begin{array}{l}\text { Syzygium guineense subsp. macrocarpum } \\
\text { Engl. }\end{array}$ & Myrtaceae & Fruit & Fruit & $2 ; 3$ & N. R \\
\hline Nkondo, Mucua & Adansonia digitata $\mathrm{L}$. & Bombacaceae & Fruit, Pulp & Jus & $2 ; 3 ; 8$ & Vul. \\
\hline Nkuwa nkuwa, N'sanu & Xylopia aethiopica (Dunal) A. Rich & Annonaceae & Fruit, seed & Spice & 2 & N. R \\
\hline $\begin{array}{l}\text { Nlondo nlondo, } \\
\text { kimbiolognua }\end{array}$ & Mondia whitei (Hook.f.) Skeels & Apocynaceae & Leaf, root & $\begin{array}{l}\text { Snacks, } \\
\text { vegetable }\end{array}$ & 1 & N. R \\
\hline Nsafu & Dacryodes edulis (G. Don) H. J. Lam & Burseraceae & Fruit & Fruit & $2 ; 3$ & N. R \\
\hline Nsala bakala & Dracaena camerooniana Baker & Asparagaceae & Leaf & Vegetable & 1 & N. R \\
\hline Nsungi, tsongo & Treculia africana Decne.ex Trécul & Moraceae & Seeds & Spice & 2 & N. R \\
\hline Pepino & Cucumis metuliferus E.Mey & Cucurbitaceae & Fruit & Vegetable & 2 & N. R \\
\hline Sangu sangu & Cymbopogon densiflorus(Steud.) Stapf & Poaceae & $\begin{array}{l}\text { Leaf, } \\
\text { inflorescence }\end{array}$ & Tea & 1 & N. R \\
\hline Tu menga menga & Landolphia lecomtei Dewère & Apocynaceae & Fruit & Fruit & $2 ; 3$ & N. R \\
\hline Wayi, mukubi & Scorodophloeus zenkeri Harms & Fabaceae & Bark, fruit & Spice & 2 & N. R \\
\hline
\end{tabular}

Legends: N.R = Nothing to report concerning the species for which there is no identified risk; Vul = Vulnerable species; Mex = Species threatened with extinction Units and modes of sale: 1: Bundle; 2: Pile/heap ; 3: Small plastic basin ; 4 : Bottles ; 5 : Plastic canister ; 6 : Liter ; 7 : Kilogram ; 8 : Bag of 50 $\mathrm{kg}$. 
TABLE 2: LIST OF EDIBLE ANIMALS NWPF SOLD IN UÍGE PROVINCE

\begin{tabular}{|c|c|c|c|c|}
\hline Local names & Scientific name & Family & Units and Modes of sale & Conservation status \\
\hline Cacusso/tilapia & Tilapia sp. & Cichlidae & Heap & Inv. \\
\hline Kamba & Chanallabes apus (Günther 1873) & Clariidae & Brochettes & N. R \\
\hline Kimpiti & Cephalophus castaneus (Thomas 1892) & Bovidae & Entire, chunks & N. R \\
\hline Kusu & Lemniscomys griselda (Thomas 1904) & Muridae & Brochettes & N. R \\
\hline Lunsua & Macrotermes subhyalinus (Rambur, 1842) & Termitidae & Kilo & Vul. \\
\hline Mansende & Gonimbrasia (Nudaurelia) dione (Fabricus 1793) & Saturniidae & Kilo, Heap & N. R \\
\hline Mansende & Imbrasia obscura (Butler 1878) & Saturniidae & Kilo, heap & N. R \\
\hline Mbala & Genetta genetta felina (Linnaeus, 1758) & Viverridae & Entire, chunks & N. R \\
\hline Mbende & Lemniscomys striatus (Linnaeus 1758) & Muridae & Brochettes & N. R \\
\hline Mboma & Python sebae (Gmelin 1788) & Pythonidae & Entire, chunks & N. R \\
\hline Nzimbula & Apis mellifera adansonii (Latreille 1804) & Apidae & Litre & N. R \\
\hline Mfuenge & Genetta tigrina (Schreber, 1778) & Viverridae & Entire, chunks & Vul. \\
\hline Mfulu tutu & Kinixys erosa (Schweigger 1812) & Testudinidae & Entire, chunks & N. R \\
\hline Milenda & Sciatta inconcisa (Walker 1869) & Noctuidae & Kilo, heaps & N. R \\
\hline Minzundu/Minzunzu & Anaphe panda (Boisduval, 1847) & Notodontidae & Kilo, heaps & N. R \\
\hline Mpakasa & Syncerus caffer nanus (Boddaert, 1785) & Bovidae & Chunks & M.ex \\
\hline Mumfungua & Non ident. & Channidae & Heap, Brochettes & N. R \\
\hline Munguela & Imbrasia epimethea (Drury 1773) & Saturniidae & Kilo, heap & N. R \\
\hline Mungusu & Parachanna obscura (Teugles \& Daget 1984) & Channidae & Entire, heap & N. R \\
\hline N'kanka & Funisciurius pyrrhopus (Cuvier, 1833) & Sciuridae & Entire & N. R \\
\hline Ngandu & Crocodylus niloticus (Laurenti ,1768) & Crocodylidaae & Heap & Vul. \\
\hline Ngembua & Epomops frangueti (Tomes 1860) & Pteropodidae & Heap, Brochettes & N. R \\
\hline Ngola & Clarias angolensis (Steindachner 1866) & Clariidae & Brochettes & N. R \\
\hline Ngone & Non ident. & Muridae & Brochettes & N. R \\
\hline Ngulu a mfuta & Potamochoerus porcus (Linnaeus 1758) & Suidae & Heap & N. R \\
\hline Ngulu a nzimba & Hystrix africaeaustralis (Peters, 1852) & Hystricidae & Entire, chunks & N. R \\
\hline Ngumbe & Fracolinus afer (Statius Müller 1766) & Phasianidae & Entire & N. R \\
\hline Nkaka & Phataginus tricuspis (Rafinesque 1821) & Manidae & Entire, chunks & N. R \\
\hline Nkayi & Tragelaphus scriptus (Pallas, 1766) & Bovidae & Entire, chunks & N. R \\
\hline Nkelele & Nimida meleagris (Linnaeus 1758) & Numididae & Entire & N. R \\
\hline Nkima & Cercopithecus ascanius (Audebert 1799) & Cercopithecidae & Entire, chunks & N. R \\
\hline Nkuati & Cirina forda (Westwood 1849) & Saturniidae & Entire, chunks & N. R \\
\hline Nkumbi & Cricetomys emini (Wroughton 1910) & Nesomyidae & Entire & N. R \\
\hline Nkumbi & Cricetomys ansorgei (Thomas 1904) & Nesomyidae & Entire & N. R \\
\hline Nlumba a londe & Lepus sp. & Leporidae & Entire & N. R \\
\hline Nsekele & Atherurus africanus (Gray 1842) & Hystricidae & Entire, chunks & N. R \\
\hline Nsengui, mbambi & Varanus niloticus (Linnaeus 1766) & Varanidae & Entire, chunks & N. R \\
\hline Nsesi & Cephalopus monticola (Thunberg 1789) & Bovidae & Entire, chunks & N. R \\
\hline Nsizi, cambuige & Thryonomys swinderianus (Temminck, 1827) & Thryonomydae & Entire, heap & N. R \\
\hline Nsombe & Rhynchophorus phoenicis (Fabricius 1801) & Curculionidae & Brochettes, heap & Vul. \\
\hline Ntoto & Mungos mungo (Gmelin 1788) & Herpestidae & Entire & N. R \\
\hline N'vanda, Mvudi & Non ident. & Bovidae & Chunks & N. R \\
\hline Nzenze & Brachytrupes membraceus (Drury 1770) & Gryllidae & Brochettes, heap & N. R \\
\hline Nzima, kombe & Civettictis civetta (Schreber 1776) & Viverridae & Entire, chunks & Vul. \\
\hline Nzombo & Protopterus dolloi (Boulenger 1900) & Protopteridae & Entire, chunks & N. R \\
\hline Nzonzi & Enteromius sp. & Cyprinidae & Brochettes, heap & N. R \\
\hline Seke & Passer spp. & Passeridae & Brochettes, heap & N. R \\
\hline
\end{tabular}

Legend: N.R = Nothing to report concerning the species for wihich there is no identified risk; Inv = Invasive species, Vul = Vulnerable species; Mex = Species threatened with extinction.

TABLE 3: LIST OF EDIBLE MYCOLOGICAL NWPFS SOLD IN UÍGE PROVINCE

\begin{tabular}{|c|c|c|c|c|c|}
\hline Local names & Scientific name & Family & $\begin{array}{l}\text { Edible } \\
\text { parts }\end{array}$ & $\begin{array}{c}\text { Units and Modes } \\
\text { of sale }\end{array}$ & $\begin{array}{c}\text { Conservation } \\
\text { status }\end{array}$ \\
\hline $\begin{array}{l}\text { Kuete kuete, Wunkulu } \\
\text { nkulu }\end{array}$ & Cantharellus sp. & Cantharellaceae & Hat & Heap & N. R \\
\hline Mvumbu, Mvubu & $\begin{array}{c}\text { Lactarius edulis (Verbeken \& } \\
\text { Buyck 1994) }\end{array}$ & Russulaceae & Hat, stem & Rosary/chapelet & N. R \\
\hline Nsempedia & $\begin{array}{c}\text { Termitomyces aurantiacus (R. } \\
\text { Heim 1942) }\end{array}$ & Lyophyllaceae & Hat, stem & $\begin{array}{l}\text { Heap, small basin } \\
\text { bassin }\end{array}$ & N. R \\
\hline Wunguvu, Unguvu, Nguvu & $\begin{array}{c}\text { Termitomyces titanicus (Pegler \& } \\
\text { Piearce) }\end{array}$ & Lyophyllaceae & Hat, stem & $\begin{array}{l}\text { Entire, heap, } \\
\text { small basin }\end{array}$ & N. R \\
\hline $\begin{array}{c}\text { Unzenga nzenga, Nkutu } \\
\text { bala }\end{array}$ & Auricularia sp. & Auriculaceae & Hat & Heap & N. R \\
\hline Nkaka matu, bukutu kutu & $\begin{array}{c}\text { Auricularia cornea (Ehrenb. } \\
1820)\end{array}$ & Auriculaceae & Hat & Heap, small basin & N. R \\
\hline Mbala ntoto & $\begin{array}{c}\text { Termitomyces mammiformis ( } \mathrm{R} . \\
\text { Heim 1942) }\end{array}$ & Lyophyllaceae & Hat, stem & Heap, small basin & N. R \\
\hline Unzawu, Nzawu & $\begin{array}{l}\text { Termitomyces microcarpus (Berk. } \\
\quad \text { \& Broome) R. Heim (1942) }\end{array}$ & Lyophyllaceae & Hat, stem & Heap, small basin & N. R \\
\hline Ntumbudia & $\begin{array}{c}\text { Termitomyces mammiformis (R. } \\
\text { Heim 1942) }\end{array}$ & Lyophyllaceae & Hat, stem & Heap, small basin & N. R \\
\hline
\end{tabular}

Legend: N.R = Nothing to report concerning the species for which there is no identified risk. 


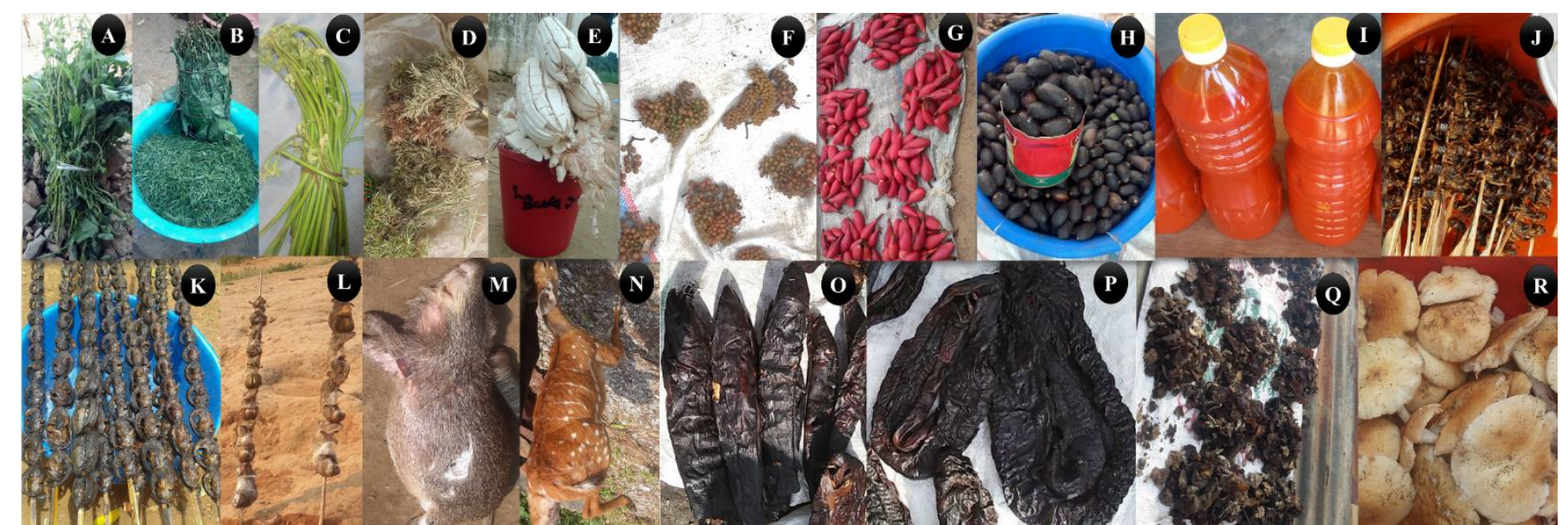

Fig. 2. Photographs of the few edible NWFPs sold in Uíge Province. a. Crassocephalum rubens; b. Gnetum africanum; c. Pteridium aquilinum; d. Cymbopogon densiflorus; e. Adansonia digitata; f. Aframommum angustifolium; g. Piper guineense; $\mathbf{h}$. Canarium schweinffurtii; i. Elaeis guineensis; j. Brachytrupes membraceus; $\mathbf{k}$. Clarias angolensis; $\mathbf{l}$. Lemniscomys striatus, L. griselda; $\mathbf{m}$. Trhyonomys swinderianus; $\mathbf{n}$. Tragelaphus scriptus; $\mathbf{0}$. Parachanna obscura; p. Protopterus dolloi; q. Auricularia cornea; r. Termitomyces aurantiacus.

\section{F. Sales Sites and Customer Loyalty Methods}

Analysis of the data from this study shows that edible NWFPs are sold in various locations in Uíge Province. Forest beverages (Elaeis guineensis and Raphia spp. wines) are sold in markets or in makeshift "barracas", roadside stands and even in homes. Also, game is sold at roadsides, market stalls and restaurants.

Finally, plants (fruit, seeds, vegetables, roots, and bark) and mushrooms are sold on roadsides, in markets, bus parking lots and even in homes. The work of Monizi et al. [7], [8] shows that the trade of edible NWFPs in Uíge province takes place in rural, peri-urban, and urban markets, roadsides, bus parking lots and even in homes.

As for customer loyalty, the results of the socio-economic surveys showed that sellers of edible NWFPs in the study area use several techniques, including selling on credit to loyal customers and granting a discount (reduction on the selling price) and a bonus to the buyer, i.e. a surplus of the purchased product. This practice is commonly known as ntelo in Kikongo language or esquebra in Angolan Portuguese.

\section{G. Savings and Income Allocation}

The majority (70.7 \%) of edible NWFP sellers in Uíge Province save their money at home. On the other hand, 29.3 $\%$ practice a kind of tontine locally called Dikelemba or Temo in Kikongo language. These results corroborate those of Monizi et al. [7] who showed that the income from the sale of NWFPs with Dracaena camerooniana leaves is kept in a kind of local tontine called Quixikila in Angolan Portuguese or Dikelemba in Kikongo language. Finally, it is necessary to note that this income generated by the sale of NWFPs helps to solve some specific and unpredictable problems of the household (assistance to parents in particular). In terms of income allocation, the money generated from the sale of edible NWFPs is used to solve several specific household problems, such as: the purchase of basic necessities, health care, bereavement, marriage, rent, clothing and beauty products, school supplies, telecommunications, etc. The results of this study corroborate those of Monizi et al. [7], [8] who worked in the same region and showed that income support contributes to the strengthening of food security, purchase of school materials, health care, basic necessities, purchase of clothes, offering to the church, cosmetics, funerals, weddings, etc. On the other hand, Lautenschläger et al. [25], have shown that the collection and sale of some edible insects is part of the livelihood diversification strategy in northern Angola and provides multiple income opportunities for households.

\section{H. Conservation Status of Edible NWFPs Sold in Uige Province}

The fauna and flora species of Angola are classified according to their statutory categories. In 2018, the Ministry of the Environment of Angola drew up a list of extinct (Extinct), endangered (Endangered), vulnerable (Vul) and invasive (Inv) plant and animal species, now called the Red List of Angolan Species. The results of the surveys of edible NWFP sellers in Uíge Province identified 8 of the 91 species on the Red List. The 8 species surveyed are Gnetum africanum, Rhynchophorus phoenicis, Adansonia digitata, Crocodylos niloticus, Civettictis civetta, Genetta tigrina, Pterocarpus angolensis (Vul), Tilapia sp (Inv) and Syncerus caffer nanus (M. ex). When questioning sellers of edible NWFPs in Uíge about the existence of a red list of plant and animal species in Angola, the answer to this question showed that none of them had ever heard of the existence of this list. Based on this answer, it is clear that the ignorance of this section of the population about the existence of the red list of species of wild flora and fauna in Angola is due to a lack of information. Furthermore, respect for the conservation of the environment would only be possible if the information provided by the Ministry of the Environment reaches $t+h e$ population in general and the sellers of edible NWFPs in particular through TV, newspapers, workshops, etc., promptly.

\section{Conclusions}

This study allowed the inventory, characterization, and valorization of some edible NWFPs marketed in Uíge Province. The results obtained reveal that the sale of forest products for food use is an activity carried out mainly by women. In addition, the study inventoried three types of 
edible NWFPs on sale in the study area, including 47 animals, 35 plants and 9 fungi. Also, edible NWFPs are sold at roadsides, bus parking lots, markets, restaurants, and vendors' homes. On the other hand, NWFPs are sold using non-standardized units of measurement. And most sellers of edible NWFPs do not display the price on their merchandise. The study also found that the income generated from the sale of NWFPs is used to solve specific household problems such as health care, weddings, clothing, school supplies, etc. The study also found that NWFPs are sold in a variety of ways. The results of this study constitute a database providing additional information on Angola's edible NWFPs, especially those sold in Uíge province. That this work be complemented by economic studies aimed at quantifying the volume of activities in this sector.

Finally, this work has just contributed to the creation of a database essential for sustainable management and the development of strategies for the organization of the edible NWFP market that will guarantee the socio-economic.

\section{REFERENCES}

[1] Food and Agriculture Organization of the United Nations. Evaluation de l'importance des produits forestiers non ligneux au Sénégal, FAO, Bureau régional de l'Afrique, Accra, Ghana, 2è édition. 2001.

[2] Food and Agriculture Organization of the United Nations. Living in and from the forests of Central Africa. Rome, Italy. 208pp, 2017.

[3] Food and Agriculture Organization of the United Nations. Towards a harmonised definition of non -wood forest produts, $\mathrm{N}^{\circ} .198$, vol. 50 . 1999a.

[4] B. Toirambe. Place des PFNL dans l'aménagement durable de la Réserve de Biosphère de Luki en R.D.C. Travail de fin d'études. Gembloux: FUSAGx. 77pp. 2005.

[5] Food and Agriculture Organization of the United Nations. Non-wood forest products for rural income and sustainable forestry. Roma. $127 \mathrm{pp}, 1995$.

[6] M. Grieg-Gran, S. Bass, F. Booker, and M. Day, The role of forests in a green economy transformation in Africa. PNUE, 2005.

[7] M. Monizi, A. Dionisio Canga, L. Lukoki, K. N. Ngbolua and N. Luyindula. Ethnobotanical and Socio-economic of Dracaena camerooniana Baker in Uíge Province, Northern Angola. Journal of Agriculture and Ecology Research International, 20 (2): pp. 1-15, 2019.

[8] M. Monizi, V. Mayawa, J. Fernando, C. Neinhuis, L. Thea. The cultural and socio-economic role of Raffia wine in the Province Uíge, Angola". Discovery, 54 (268), pp. 119-129, 2018.

[9] M. Mawunu, K. Bongo, E. Afonso, M. M. Za Vua, L. Ndiku et K. N. Ngbolua. Contribution à la connaissance des produits forestiers non ligneux de la Municipalité d'Ambuila (Uíge, Angola): Les plantes sauvages comestibles. International Journal of Innovation and Scientific Research, 26, pp. 190-204, 2016.

[10] Gumbo D. Regional review of SFM and policy approaches to promote it - sub-Saharan Africa. Background Paper for the forests chapter In: UNEP, Towards a Green Economy: Pathways to Sustainable Development and Poverty Eradication, UNEP, 2011.

[11] P. Vedeld, A. Angelsen, E. Sjaastad and G. Kobugabe Berg. Counting on the environment: forest incomes and the rural poor. Environmental Economics Series, Paper No. 98, World Bank Environment Department, World Bank, Washington, D.C, 2004.

[12] Food and Agriculture Organization of the United Nations. State of the world's forests, 2014. Enhancing the socioeconomic benefits from forests. Food and Agriculture Organization of the United Nations, Rome, 2014

[13] O. Ndoye, M. Ruiz Perez, et A. Eyebe,. The market of non-timber forest products in the humid forest zone of Cameroon. ODI Rural Development Forestry network (22) ODI, London, 1998.

[14] M.A.C. Bikoue et H. Essomba. Gestion des ressources naturelles fournissant les PFNL alimentaire en Afrique centrale. 104pp, 2007.

[15] H War. La gestion participative et le développement des PFNL comme moyen de réduction de la pauvreté feminine en zones rurales: cas du Maghreb et du Sahel, mémoire de DESS, Faculté des Hautes Etudes en Gestion de la Politique Economique, Cocody. 76p, 2007.
[16] C. Moupela, C. Vermeulen, K. Daïnou and J.-J. Doucet. Le noisetie d'Afrique (Coula edulis Baill.). Un produit forestier non ligneux méconnu", Biotechnol. Agron. Soc. Environ. 15 (3) pp. 451-461, 2011.

[17] BafD (Groupe de la Banque africaine de développement). Rapport sur le développement en Afrique 2012. Vers une croissance verte en Afrique. Tunis, Tunisie". 169 pp, 2013.

[18] B.P. Mulenga, R. B. Richardson, and G. Tembo. Non-Timber Forest Products and Rural Poverty Alleviation in Zambia.Working Paper No. 62 April 2012. Indaba Agricultural Policy Research Institute (IAPRI) Lusaka, Zambia, 2006.

[19] Tinde van Andel. Non Timber Forest Products. The value of wild plants. Digigrafi, Wageningen, The Netherlands.71pp, 2006.

[20] E.T. Noubissie, J. Chupezi and O. Ndoye. Studies on the Socioeconomic Analysis of Non-Timber Forest Products in Africa Synthesis of reports of studies in the project GCP/RAF/398/GER, Yaounde, Cameroon, FAO GCP/RAF/398/GER, 2008.

[21] N.M. Chidebere-Mark, R.D. Ejike and U.N. Akwiwu. Economics of non-timber forest products (NTFPS) marketing in IKWUANO local government area, Abia.

[22] State, Nigeria". European Journal of Agriculture and Forestry Research Vol.4, No.2, pp.1-8, 2016.

[23] Food and Agriculture Organization of the United Nations. Angola. Séminaire sur les statistiques forestières en Afrique, by D. Veloso \& R. Manza. Thiès, Sénégal, 1991

[24] Food and Agriculture Organization of the United Nations. NWFP statistics: Angola, by A. ZOLA. EC - FAO Partnerships Programme, Project GCP/INT/679/EC/FAO. Rome, 1996b.

[25] T. Lautenschlager, C. Neinhuis. Riquezas naturais de Uíge-uma breve introdução sobre o estado atual, a utilização, a ameça e a preservação da biodiversidade. Dresden, Germany, 2014.

[26] T. Lautenschläger, C. Neinhuis, M. Monizi, J. L. Mandombe, A. Förster, T. Henle, M. Nuss. Edible insects of Northern Angola". African Invertebrates 58(2): pp. 55-82, 2017.

[27] Instituto Nacional de Estatística de Angola. Resultados definitivos do Recenseamento geral da População e Habitação de Angola 2014 Luanda. Angola, 2016.

[28] M. C. Peel, B. L. Finlayson, T. A. McMahon. Updated world map of the Köppen-Geiger climate classification, Hydrology and Earth System Sciences 11(5): pp.1633-44, 2007.

[29] D.J. Briggs and P. Smithson. Fundamentals of physical geography: Rowman \& Littlefield, 1986.

[30] Perfil da Provincia do Uíge. Governo Provincial do Uíge, Angola, 2012.

[31] T. Lautenschläger, M. Monizi, M. Pedro, J. L. Mandombe, M. Futuro Bránquima, C. Heinze and C. Neinhuis. First large-scale ethnobotanical survey in the province of Uíge, northern Angola Journal of Ethnobiology and Ethnomedicine. 14:51, 2018.

[32] Ministério de Ambiante. Lista Vermelha das Espécies de Angola. Direção Nacional da Biodiversidade, 2018.

[33] P. Latham and A. Kondo ku Mbuta. Plants of Kongo Central province, Democratic Republic of Congo. U.K, 2017.

[34] S. Dibaluka Mpulusu. Étude des macromycètes de la cité de Kimvula et de ses environs (Bas-Congo/R.D. Congo): Diversité et productivité en forêt claire, ethnomycologie et mise en culture d'espèces saprotrophes comestibles. Thèse de doctorat inédite Fac. Sc. Université de Kinshasa, Kinshasa, 468 pp, 2012.

[35] J. Kingdon. The Kingdon field guide to African mammals. Academic Press, London, 2000. 


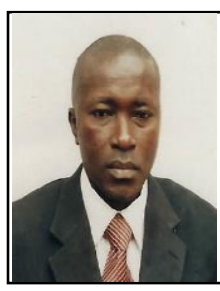

Mr. Monizi Mawunu, was born on 27th September and obtained his BSc in Biotechnology in 2003 from the University of Kinshasa, and MSc in sustainable food in 2013 from Montpellier SupAgro-Institut des Régions Chaudes. He published several papers (19) in international journals. His field of research are ethnobotany, ethnobiology, ethnopharmacology, endogenous knowledge, food and medicinal plants. $\mathrm{He}$ is Lecturer at Kimpa Vita University in Uige Province, Angola and he is Master of Science student in Biology at the University of Kinshasa, Democratic Republic of the Congo.

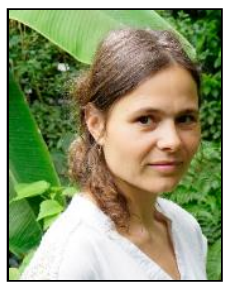

Dr. Thea Lautenschläger obtained her Ph.D. in the Institute of Botany, Technische Universität Dresden, Germany, in 2011. Since 2012, she is the head of the Ethnobiology working group with the focus on studies in Angola. Further areas of interest are biomechanics and didactics. She has published over 40 publications in reputable national and international journals.

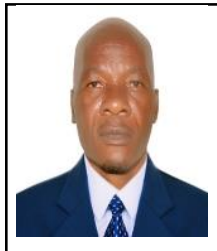

Mr. Masidivinga Landu was born on the $3^{\text {rd }}$ Nevember. He obtained his BSc degree in Economics, from the University of Kinshasa, Democratic Republic of the Congo in 1997. He obtained also a master's degree in accounting and Finance from the Higher Institute of Accounting and administration in Pirto (Portugal). He is Lecturer in the University Kimpa Vita (Uige) in Angola and speaker of several conference announcements.

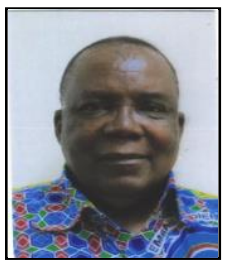

Professor Luyindula Ndiku Sébastien holds a degree in Science from the Lovanium University of Kinshasa (1971) and a Doctorate in Science from the State University in Liège (Belgium, 1977). Former trainee at the Laboratory of Cell Biochemistry in the Department of Radiobiology at the Center for Nuclear Studies in Mol (Belgium), Professor Luyindula has carried out research on the molecular approach to the phenomenon of symbiosis between bacteria of the genus Rhizobium and legumes. He has extensively studied the phenomenon of biological nitrogen fixation and protein productivity of legumes and has specialized in the use of isotopes and nuclear techniques for the study of Sol-plant relationships. He masters in vitro plant tissue culture techniques. In 1987, Professor Luyindula was visiting Scientist at the University of Texas A\&M, College Station (USA) and During the years 1989 and 1990 worked as an associate researcher at the International Center for Livestock Institute (ILRI) based in Addis Ababa (Ethiopia). Later, in May 1994, he visited the Universities of Delaware (Newark) and Hawaii (Niftal) in the USA; In April 2005, he made a study trip to the Laboratory of Biotechnology and Androgenesis, University of Picardie, Jules Verne, Amiens/France. Professor LUYINDULA is Director of Research and Scientific Director of the General Commissariat for Atomic Energy (CGEA) and teaches plant biology and biotechnology at the University of Kinshasa and the other Universities in the Democratic Republic of Congo. Honorary Rector of the Protestant University of Kimpese (Kongo Central, $\mathrm{DRC}$ ), he is author or co-author of more than 80 scientific publications and Promoter or Co-Promoter of several $\mathrm{PhD}$ theses in Sciences.

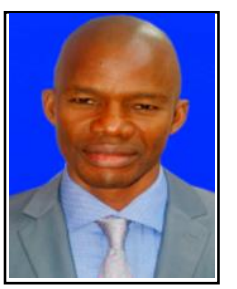

Dr. K.N. Ngbolua was born in Abuzi, Nord-Ubangi Province, Democratic Republic of the Congo (DRC) on October 27, 1972. He obtained his Bachelor of Science in Biology (Biotechnology), from the University of Kinshasa, DRC in 2002; Master of Science in Molecular Biology from the same University in 2005. He is Doctor of Philosophy in Molecular Biology from the University of Kinshasa and Malagasy Institute of Applied Research (IMRA, Madagascar) since 2012. Dr Ngbolua is Full Professor of Molecular biology, Biochemistry and Biophysics at the University of Kinshasa and currently serves as the Chancellor/Rector of the University of Gdado-Lite (Province of Nord-Ubangi) in DRC. He has his expertise in Biodiversity monitoring and Biological evaluation of medicinal plants (Bioguided fractionation assays) and structural characterization of bioactive secondary metabolites of relevance for improving the human health and wellbeing. Prof. Ngbolua is member of American Society for Cell Biology (ASCB), USA. His H-index is: 33 (ReasearchGate); 30 (Google Scholar).

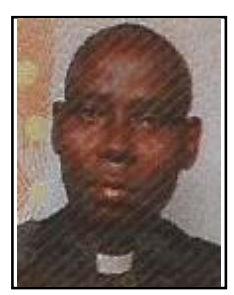

Dr. Félicien Lukoki Luyeye was born in Kisunda, Kongo Central Province, DRC on the $01^{\text {th }}$ May 1947 $\mathrm{He}$ holds a state diploma of Scientic Humanities (Biochemistry) from the Scholar Medical Center of Kisantu in 1966. He is a candidate in Biological and Agricultural Sciences from the Lovanium University in 1970 and an Agricultural Engineer of Tropical Regions from the National University of Zaire, Kinshasa Campus in 1973. His is Doctor of Philosophy in Agricultural Sciences from the State Faculty of Agronomic Sciences in Gembloux (Belgium) in 1980. Former Ordinary Professor of the Faculty Institute of Agronomic Sciences (IFA) of Yangambi, Former Professor of Seminary of Mayidi. Former Dean of the Faculty of Economics and Development and Honorary Vice-Rector of the Catholic University of Congo, he is currently Ordinary Professor at the Department of Biology, Faculty of Science, University of Kinshasa, Director of the Herbarium IUK of Kinshasa and Head of the Laboratory of Systematic Botany and plant Ecology at the Department of Biology. He is the author of several scientific publications in the field of plant ecology. He is the author of the books such as "Traditional Kongo Medecine -Nkisi mi Bakulu".

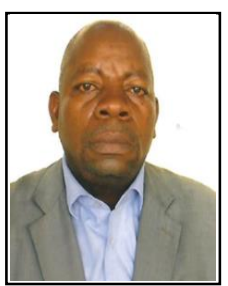

Mr. Macuntima Pedro was born in Damba (Uige) in the Rupublic of Angola on June 16, 1969. He is holder of a Diploma of Scientific Humanities B (Biochemistry) from the Pre-University Center (PUNIV) of Uige in 1988. He did his University studies at the Agronomic and Veterinary Institute of Mohamed V University in Rabat, Kingdom of Morocco (Horticultural Complex of Agadir) obtaining the Diploma of Graduation in Horticulture and Physiatry in 1994. Subsequently, he obtained his bachelor and MSc $(1997,1999)$ in forestry at the National Forestry Schoo of Engineers in Rabat, Kingdom of Morocco. He is currently teaching at Kimpa Vita University Uige, Republic of Angola. 